DOI: $10.19195 / 0137-1134.107 .15$

\title{
SWOBODA PRZEMIESZCZANIA SIĘ STUDENTÓW W UNII EUROPEJSKIEJ — PRAWO DOSTĘPU DO SZKOLNICTWA WYŻSZEGO I STYPENDIÓW W KONTEKŚCIE TRANSNARODOWYM
}

\section{WPROWADZENIE}

Zgodnie z art. 14 ust. 1 Karty Praw Podstawowych Unii Europejskiej każdy ma prawo do nauki i dostępu do kształcenia zawodowego i ustawicznego. W art. 14 ust. 2 Karty Praw Podstawowych wskazano, że prawo to obejmuje możliwość korzystania z bezpłatnej nauki obowiązkowej. Natomiast zgodnie z art. 14 ust. 3 KPP UE wolność tworzenia placówek edukacyjnych z właściwym poszanowaniem zasad demokratycznych i prawo rodziców do zapewnienia wychowania oraz nauczania dzieci zgodnie $\mathrm{z}$ własnymi przekonaniami religijnymi, filozoficznymi i pedagogicznymi są szanowane zgodnie z ustawami krajowymi regulującymi korzystanie z tej wolności i z tego prawa. Artykuł 14 Karty Praw Podstawowych nie był dotychczas przedmiotem interpretacji Trybunału Sprawiedliwości Unii Europejskiej. Nie oznacza to jednak, że prawo do edukacji pozostaje w ogóle poza zakresem uwagi prawa Unii Europejskiej, w tym orzecznictwa Trybunału Sprawiedliwości. W konsekwencji wydaje się, że także prawo do nauki i dostępu do kształcenia zawodowego i ustawicznego, gwarantowane na podstawie Karty Praw Podstawowych, powinno być już obecnie interpretowane w świetle dotychczasowego dorobku prawa Unii Europejskiej, w tym stanowiska Trybunału Sprawiedliwości ${ }^{1}$.

1 Poza zakresem opracowania pozostaje orzecznictwo Europejskiego Trybunału Praw Człowieka w odniesieniu do prawa do nauki, na ten temat zob. J. Sobczak, Komentarz do art. 14 Karty Praw Podstawowych UE, [w:] Karta Praw Podstawowych. Komentarz, red. A. Wróbel, Warszawa 2012, s. 562-571; G. Gori, Article 14, [w:] The EU Charter of Fundamental Rights. A Commentary, red. S. Peers et al., Oxford-Portland-Oregon 2014, s. 408-411. 
Kompetencje Unii Europejskiej w dziedzinie edukacji mają ograniczony charakter, ponieważ obejmują jedynie podejmowanie działań wspierających, koordynujących i uzupełniających działania państw członkowskich ${ }^{2}$. Zgodnie z art. 165 ust. 1 TFUE Unia ma przyczyniać się do rozwoju edukacji o wysokiej jakości przez zachęcanie do współpracy między państwami członkowskimi oraz, jeśli jest to niezbędne, przez wspieranie i uzupełnianie ich działalności przy jednoczesnym poszanowaniu odpowiedzialności państw członkowskich zarówno za treść nauczania i organizację systemów edukacyjnych, jak również ich różnorodność kulturową i językową. Zgodnie z art. 165 ust. 2 TFUE działanie Unii zmierza m.in. do sprzyjania mobilności studentów i nauczycieli, na przykład przez zachęcanie do akademickiego uznawania dyplomów i okresów studiów. Ponadto zgodnie $z$ art. 166 ust. 1 TFUE Unia ma urzeczywistniać politykę kształcenia zawodowego, która wspiera i uzupełnia działanie państw członkowskich, przy pełnym poszanowaniu odpowiedzialności państw członkowskich za treść i organizację kształcenia zawodowego. W tym zakresie działania Unii zmierzają m.in. do ułatwiania dostępu do kształcenia zawodowego oraz sprzyjania mobilności nauczycieli i kształcących się, a zwłaszcza młodzieży. W obu przypadkach (odpowiednio zgodnie z art. 165 ust. 4 i art. 166 ust. 4 TFUE) środkami realizacji ww. celów UE mogą być ,środki zachęcające, z wyłączeniem jakiejkolwiek harmonizacji przepisów ustawowych i wykonawczych państw członkowskich" oraz zalecenia przyjmowane przez Radę na wniosek Komisji Europejskiej ${ }^{3}$. W konsekwencji akty prawa pochodnego Unii Europejskiej w dziedzinie dostępu do kształcenia wyższego i uniwersyteckiego nie mogą być źródłem uprawnień dla jednostek w tym zakresie.

Źródłem uprawnień, jakie studenci — obywatele Unii Europejskiej — wywodzą z prawa UE, są natomiast bezpośrednio skuteczne przepisy TFUE statuujące zasadę niedyskryminacji ze względu na obywatelstwo (art. 18 TFUE), swobodę przemieszczania się i pobytu obywateli UE (art. 21 TFUE), a także swobodę przepływu pracowników (art. 45 TFUE) i swobodę przedsiębiorczości (art. 49 TFUE). Zatem wpływ prawa Unii Europejskiej na status studentów korzystających ze swobody przemieszczania się w celu podjęcia i odbycia studiów w szkołach wyższych w państwach członkowskich innych niż ich państwo obywatelstwa materializuje się przez oddziaływanie bezpośrednio skutecznych przepisów TFUE, a nie przez harmonizację ustawodawstw krajowych państw członkowskich dokonywaną na podstawie upoważnień zawartych $\mathrm{w}$ TFUE.

Biorąc pod uwagę powyższe, w niniejszym opracowaniu dokonano analizy wynikających z prawa UE uprawnień, jakie studenci wywodzą bezpośrednio ze skutecznych przepisów TFUE w sytuacji, gdy korzystają ze swobody przemiesz-

2 Por. art. 6 pkt e) Traktatu o funkcjonowaniu UE, który wśród obszarów objętych tymi kompetencjami UE wymienia edukację, kształcenie zawodowe, młodzież i sport.

${ }^{3}$ Szerzej por. A. Siwek-Ślusarek, Komentarz do art. 165 i 166 Traktatu o funkcjonowaniu Unii Europejskiej, [w:] Traktat o funkcjonowaniu Unii Europejskiej. Komentarz, t. II, red. A. Wróbel, K. Kowalik-Bańczyk, M. Szwarc-Kuczer, s. 1011-1031, wraz z podaną literaturą. 
czania się i pobytu obywateli UE w celu podjęcia i odbycia studiów w szkołach wyższych (w innych państwach członkowskich).

Rozważania dotyczyć będą dwóch obszarów: 1) prawa dostępu do kształcenia wyższego i uniwersyteckiego przysługującego studentom migrującym, tzn. osobom które wyjeżdżają z państwa członkowskiego pochodzenia do innego państwa członkowskiego w celu podjęcia studiów; 2) prawa dostępu do stypendiów i pożyczek studenckich, których celem jest zachęcanie do studiowania i ułatwianie go, przy czym odrębnie należy analizować sytuację obywateli innych państw członkowskich w państwie przyjmującym oraz sytuację obywateli danego państwa członkowskiego przyznającego stypendium, którzy korzystając ze swobody przemieszczania się, studiują lub zamierzają studiować w innych państwach członkowskich.

\section{PRAWO DOSTĘPU DO KSZTAŁCENIA WYŻSZEGO I UNIWERSYTECKIEGO}

\subsection{DOSTĘP DO KSZTAŁCENIA WYŻSZEGO I UNIWERSYTECKIEGO JAKO KWESTIA OBJĘTA ZAKRESEM STOSOWANIA PRAWA UE}

Podstawową kwestią wymagającą rozstrzygnięcia przy rozpatrywaniu sytuacji osób, które podejmują studia w państwie członkowskim innym niż państwo pochodzenia, jest ustalenie, czy prawo dostępu do kształcenia wyższego i uniwersyteckiego można w ogóle wywodzić z prawa Unii Europejskiej. Innymi słowy konieczna jest odpowiedź na pytanie, czy kwestia dostępu do kształcenia wyższego i uniwersyteckiego w ogóle wchodzi w zakres stosowania prawa Unii Europejskiej, zważywszy na ograniczone kompetencje Unii Europejskiej w dziedzinie edukacji.

Trybunał Sprawiedliwości potwierdza konsekwentnie, że po pierwsze przesłanki dostępu do kształcenia zawodowego są objęte zakresem stosowania Traktatu ${ }^{4}$ oraz pod drugie — że zarówno kształcenie wyższe, jak i uniwersyteckie stanowią kształcenie zawodowe ${ }^{5}$. Konsekwencją uznania, że kształcenie wyższe i uniwersyteckie wchodzą w zakres stosowania prawa UE, jest przyjęcie, że także w tej dziedzinie obywatele UE korzystają z ochrony przed dyskryminacją ze względu na obywatelstwo. W wyroku Bressol Trybunał Sprawiedliwości z jednej strony podkreślił, że prawo Unii nie narusza kompetencji państw członkowskich w dziedzinie organizacji ich systemów edukacji i kształcenia zawodowego 6 . Z drugiej strony jednak wskazał, że przy wykonywaniu tych kompetencji państwa

4 Wyrok Gravier, 293/83, EU:C:1985:69, pkt 25; wyrok Komisja p. Belgii, C-65/03, EU:C:2004:402, pkt 25; wyrok Komisja p. Austrii, C-147/03, EU:C:2005:427, pkt 32.

5 Wyrok Blaizot, 24/86, EU:C:1988:43, pkt 15-20; wyrok Komisja p. Belgii, 42/87, EU:C:1988:454, pkt 7-8; wyrok Komisja p. Austrii, EU:C:2005:427, pkt 33.

${ }^{6}$ Odwołując się do wyraźnego brzmienia ob. art. 165 i 166 TFUE. 
członkowskie powinny przestrzegać prawa Unii, w szczególności przepisów dotyczących swobody przemieszczania się i swobody pobytu na terytorium państw członkowskich ${ }^{7}$. Państwa członkowskie dysponują zatem swobodą wyboru i mogą ustanowić system kształcenia oparty na otwartym dostępie (bez ograniczeń przyjmowanych studentów) lub też system oparty na selekcji studentów, jednakże założenia i podstawy funkcjonowania każdego z nich muszą być zgodne $\mathrm{z}$ prawem UE, w szczególności z zasadą niedyskryminacji ze względu na przynależność państwową ${ }^{8}$.

W obecnym stanie prawa UE nie powinno być więc żadnych wątpliwości, że kwestia dostępu do kształcenia wyższego i uniwersyteckiego wchodzi w zakres stosowania prawa UE, w szczególności na potrzeby stosowania zasady niedyskryminacji ze względu na obywatelstwo (zagwarantowanej na podstawie art. 18 TFUE) oraz zagwarantowania swobody przemieszczania się i pobytu na terytorium państw członkowskich (na podstawie art. 21 TFUE).

\subsection{ZAKRES PRZEDMIOTOWY ZAKAZU DYSKRYMINACJI ZE WZGLĘDU NA OBYWATELSTWO W ZAKRESIE DOSTĘPU DO KSZTAŁCENIA WYŻSZEGO I UNIWERSYTECKIEGO}

Kolejną istotną kwestią jest zakres ochrony zagwarantowany na podstawie przepisów prawa UE w zakresie dostępu do kształcenia wyższego i uniwersyteckiego dla obywateli UE w państwach członkowskich innych niż ich państwo pochodzenia, tzn. ustalenie, czy studenci chronieni są jedynie przed jawną dyskryminacją ze względu na obywatelstwo, czy też przysługuje im ochrona także przed dyskryminacją pośrednią. W tym zakresie należy stwierdzić, że podejście Trybunału Sprawiedliwości do tej kwestii uległo istotnej ewolucji. Interpretacja zasady niedyskryminacji ze względu na obywatelstwo, przyjęta przez UE, prowadzi do przyznania studentom szerokiego dostępu do kształcenia w ramach szkolnictwa wyższego państw członkowskich innych niż ich państwo pochodzenia, a z drugiej strony - do coraz bardziej widocznego ograniczania swobody państw członkowskich w zakresie regulowania warunków rekrutacji na studia. W obecnym stanie prawa UE zakazana jest bowiem zarówno dyskryminacja bezpośrednia ze względu na obywatelstwo, jak również dyskryminacja pośrednia, chyba że może być ona uzasadniona względami obiektywnymi nieopartymi na obywatelstwie i proporcjonalna do zamierzonego przez państwo członkowskie celu.

Początkowo, w latach 80. XX w., w wyroku Gravier Trybunał uznał, że stanowi dyskryminację ze względu na obywatelstwo - sprzeczną z art. 18 TFUE (wg obecnej numeracji) — nałożenie na studentów będących obywatelami innego państwa członkowskiego opłaty rejestracyjnej przy rekrutacji do kształcenia za-

7 Wyrok Bressol, C-73/08, EU:C:2010:181, pkt 28, oraz cytowane tam orzecznictwo.

8 Ibidem, pkt 29. 
wodowego w sytuacji, gdy taka opłata nie jest pobierana od studentów będących obywatelami państwa przyjmującego 9 .

W następnym etapie rozwoju orzecznictwa Trybunał Sprawiedliwości wywiódł z zasady niedyskryminacji ze względu na obywatelstwo także zakaz dyskryminacji pośredniej. W sprawie Komisja p. Austrii (C-147/03) przedmiotem analizy Trybunału były przepisy, na podstawie których osoby posiadające dyplom ukończenia nauki w szkole średniej, uzyskany w innych państwach członkowskich, oprócz obowiązku spełnienia ogólnych przesłanek dostępu do kształcenia na poziomie wyższym lub uniwersyteckim miały obowiązek dodatkowo wykazać, że spełniają przesłanki wstępu na wybrany kierunek - lecz ustanowione przez to państwo, które wydało dyplom (czyli innymi słowy dodatkowo musiał być spełniony warunek, że student dostał się lub dostałby się na studia w swoim państwie pochodzenia). Trybunał w pierwszej kolejności wskazał, że zasada równego traktowania zakazuje nie tylko jawnej dyskryminacji ze względu na przynależność państwową, lecz także wszelkich ukrytych form dyskryminacji, które przez stosowanie innych kryteriów rozróżniających powodują de facto ten sam skutek ${ }^{10}$. Zdaniem Trybunału, chociaż analizowany przepis krajowy miał zastosowanie jednakowo wobec wszystkich absolwentów szkół średnich, to jednak w znacznie większym stopniu dotykał obywateli innych państw członkowskich z tego powodu, że osoby posiadające dyplom ukończenia szkoły średniej uzyskany w państwie członkowskim innym niż Austria (państwo członkowskie przyjmujące) nie mogły uzyskać dostępu do kształcenia na poziomie wyższym w Austrii na takich samych warunkach, jak osoby posiadające równoważny dyplom austriacki ${ }^{11}$.

Z kolei przedmiotem analizy w sprawie Bressol były przepisy belgijskie ograniczające dostęp do studiów medycznych. Na ich podstawie nieograniczony dostęp do tych studiów przysługiwał osobom uznawanym w zgodzie z prawem krajowym za rezydentów, tzn. mającym główne miejsce zamieszkania w Belgii, i dodatkowo spełniającym co najmniej jedną z ośmiu przesłanek enumeratywnie wskazanych w przepisach (np. posiadanie prawa stałego pobytu, zamieszkiwanie co najmniej sześć miesięcy poprzedzających zapisanie się na uniwersytet itp.). Natomiast osoby niespełniające powyższych przesłanek, tzw. nierezydenci w rozumieniu przepisów krajowych, korzystały z ograniczonej możliwości dostępu, uzależnionej co do zasady od liczby chętnych rezydentów. Trybunał także w tej sprawie uznał, że przepisy krajowe wprowadzają nierówne traktowanie między studentami będącymi rezydentami i niebędącymi rezydentami. Wymóg miejsca zamieszkania w ocenie Trybunału jest w oczywisty sposób łatwiejszy do spełnienia dla obywateli danego państwa członkowskiego, którzy najczęściej mają miejsce zamieszkania w Belgii,

\footnotetext{
9 Wyrok Gravier, EU:C:1985:69, pkt 26.

10 Wyrok Komisja p. Austrii, EU:C:2005:427, pkt 46.

11 Ibidem, pkt 46-47.
} 
niż dla obywateli innych państw członkowskich, którzy najczęściej mają miejsce zamieszkania w innym państwie członkowskim ${ }^{12}$.

Konsekwencją wyroków w sprawach Komisja p. Austrii i Bressol było zatem istotne rozszerzenie zakresu przedmiotowego ochrony dostępu do szkolnictwa wyższego i uniwersyteckiego, ponieważ zakaz dyskryminacji ze względu na obywatelstwo obejmuje zarówno dyskryminację bezpośrednią (opartą wprost na kryterium obywatelstwa), jak również zakaz dyskryminacji pośredniej (nieopartej wprost na kryterium obywatelstwa, lecz sprowadzającej się do gorszego traktowania obywateli z innych państw członkowskich). Warto w tym miejscu zwrócić uwagę, że stanowisko TSUE w odniesieniu do uprawnień studentów migrujących jest w pełni spójne z podejściem stosowanym względem obywateli UE migrujących z jednego państwa członkowskiego do innego. Przykładem tego podejścia może być wyrok Trybunału Sprawiedliwości w sprawie Gottwald, w którym stwierdził on dyskryminację pośrednią w kontekście przepisów przyznających osobom niepełnosprawnym uprawnienie do bezpłatnych przejazdów autostradami ${ }^{13}$.

Dyskryminacja pośrednia (np. taka jak we wskazanych sprawach - Komisja p. Austrii oraz Bressol) może być uznana za uzasadnioną — i w konsekwencji za zgodną z zakazem dyskryminacji — jedynie wówczas, gdy jest oparta na obiektywnych przesłankach niezależnych od przynależności państwowej osób zainteresowanych i proporcjonalna do celu, do jakiego zasadnie dąży prawo krajowe ${ }^{14}$. Odnosząc się do argumentów powoływanych przez rząd austriacki w sprawie Komisja p. Austrii, Trybunał odrzucił uzasadnienie wskazujące na konieczność zachowania jednolitości austriackiego systemu kształcenia na poziomie wyższym lub uniwersyteckim oraz respektowania zobowiązań międzynarodowych wynikających z konwencji zawartych przez Austrię. Trybunał odrzucił także argument opierający się na konieczności zapobiegania nadużyciom prawa unijnego. Ponadto odniósł się do argumentacji państwa członkowskiego wskazującej na możliwość nadużywania prawa przez obywateli państwa członkowskiego, którzy nie dostali się na studia we własnym państwie obywatelstwa i z tego względu poszukiwali możliwości studiowania w innym. Odnosząc się do tego argumentu, Trybunał przypomniał, że istnienie zachowania oszukańczego bądź polegającego na nadużyciu prawa powinno być przedmiotem indywidualnego badania w każdym konkretnym przypadku i powinno opierać się na elementach obiektywnych. Podkreślił także, że z przepisów traktatów wynika, iż działanie Unii zmierza do sprzyjania mobilności studentów i nauczycieli — między innymi przez zachęcanie do akademickiego uznawania dyplomów i okresów studiów oraz do ułatwiania dostępu do kształcenia zawodowego i sprzyjania mobilności instruktorów i kształcących się, zwłaszcza młodzieży ${ }^{15}$. Zatem możliwość dostępu do systemu kształcenia na

12 Wyrok Bressol, EU:C:2010:181, pkt 44-45.

13 Wyrok Gottwald, C-103/08, EU:C:2009:597.

14 Wyrok Komisja p. Austrii, EU:C:2005:427, pkt 48; wyrok Bressol, EU:C:2010:181, pkt 41.

15 Art. 165 i 166 TFUE. 
poziomie wyższym lub uniwersyteckim, przyznana osobie, która uzyskała dyplom ukończenia szkoły średniej w innym państwie członkowskim, na takich samych warunkach jak osobom posiadającym taki dyplom uzyskany w państwie członkowskim przyjmującym, jest właśnie istotą gwarantowanej przez traktat zasady swobodnego przemieszczania się studentów. Sama w sobie zatem nie może stanowić nadużycia prawa ${ }^{16}$.

Podsumowując tę część rozważań, należy zatem stwierdzić, że w obecnym stanie prawa Unii Europejskiej, w szczególności w świetle orzecznictwa TSUE, studenci migrujący w celu podejmowania studiów w państwie członkowskim innym niż kraj ich pochodzenia korzystają z ochrony przed dyskryminacją ze względu na obywatelstwo. Walor bezpośredniej skuteczności, jaki ma zasada niedyskryminacji ze względu na obywatelstwo w zakresie, w jakim sytuacja danego obywatela jest objęta prawem UE, umożliwia studentom powoływanie się przed organami państwa członkowskiego przyjmującego w celu zakwestionowania ewentualnego zróżnicowania (wg kryterium obywatelstwa) opłat związanych ze studiami lub innych warunków rekrutacji z uwagi na niezgodność z ww. zasadą. Oznacza to także, że państwa członkowskie co prawda mają nadal kompetencje do kształtowania swoich systemów szkolnictwa wyższego i uniwersyteckiego, jednakże zarówno kwestia opłat związanych ze studiowaniem, jak również innych warunków rekrutacji nie mogą prowadzić do bezpośredniej lub pośredniej dyskryminacji ze względu na obywatelstwo.

\subsection{ZAKRES PODMIOTOWY ZAKAZU DYSKRYMINACJI W ODNIESIENIU DO DOSTĘPU DO KSZTAŁCENIA WYŻSZEGO I UNIWERSYTECKIEGO}

Wydaje się, że ochroną przed dyskryminacją bezpośrednią i pośrednią odniesieniu do dostępu do kształcenia wyższego i uniwersyteckiego objęci są wszyscy obywatele UE bez względu na stopień integracji z państwem członkowskim przyjmującym. Trybunał Sprawiedliwości potwierdził, że każdy obywatel Unii może powołać się na art. 18 TFUE zakazujący wszelkiej dyskryminacji ze względu na przynależność państwową we wszystkich sytuacjach należących do zakresu zastosowania ratione materiae prawa UE, do których należy wykonywanie swobody przemieszczania się i przebywania na terytorium państw członkowskich przyznanej na podstawie art. 21 TFUE. Jak już wskazano, zakaz ten obejmuje m.in. sytuacje dotyczące kształcenia zawodowego, którym jest kształcenie przez szkoły wyższe i kształcenie uniwersyteckie ${ }^{17}$. Należy zatem przyjąć, że bez względu na stopień integracji ze społeczeństwem państwa członkowskiego przyjmującego dostęp do kształcenia w ramach szkolnictwa wyższego i uniwersyteckiego na niedyskryminacyjnych zasadach przysługuje wszystkim obywatelom UE korzystającym ze swobody przemieszczania się.

16 Wyrok Komisja p. Austrii, EU:C:2005:427, pkt 68-70.

17 Wyrok Bressol, EU:C:2010:181, pkt 31-32. 
Jak zostanie wskazane poniżej, ten szeroki i jednolity krąg beneficjentów zakazu (bezpośredniej i pośredniej) dyskryminacji ze względu na obywatelstwo jest charakterystyczny jedynie w odniesieniu do dostępu do kształcenia wyższego i uniwersyteckiego. W odniesieniu do dostępu do stypendiów i grantów sytuacja prawna obywateli UE może znacznie się różnić.

\section{PRAWO DOSTĘPU DO STYPENDIÓW I POŻYCZEK STUDENCKICH}

\subsection{DOSTĘP DO STYPENDIÓW DLA OBYWATELI UE JAKO KWESTIA OBJĘTA ZAKRESEM STOSOWANIA PRAWA UE}

Prawo Unii Europejskiej w zakresie dostępu do stypendiów w państwie członkowskim przyjmującym dla studentów będących obywatelami innych państw członkowskich przeszło istotną ewolucję, gdyż kwestia ta dopiero z czasem została uznana za wchodzącą w zakres stosowania prawa UE, przy czym moment ten zbiegł się w czasie z ustanowieniem obywatelstwa UE.

Jeszcze w latach 80. XX wieku Trybunał Sprawiedliwości stwierdził, że w ówczesnym stanie rozwoju prawa wspólnotowego pomoc udzielana studentom na utrzymanie i kształcenie co do zasady znajduje się poza zakresem Traktatu (wówczas Traktatu ustanawiającego Europejską Wspólnotę Gospodarczą) na potrzeby stosowania ówczesnego art. 7 Traktatu (ob. art. 18 TFUE), tzn. zasady niedyskryminacji ze względu na przynależność państwową. Wówczas Trybunał stał na stanowisku, że kwestia tej pomocy mieści się w zakresie polityki edukacyjnej, która jako taka nie została powierzona instytucjom ówczesnej Wspólnoty, oraz jednocześnie — w zakresie polityki społecznej, która co do zasady należy do kompetencji państw członkowskich (z wyjątkiem tych aspektów, które są objęte szczególnymi postanowieniami Traktatu) ${ }^{18}$. W praktyce oznaczało to, że studenci podejmujący studia w innych państwach członkowskich jako obywatele państw członkowskich nieaktywni zawodowo nie mogli powoływać się przed organami i sądami państwa członkowskiego przyjmującego na ochronę wynikającą z zasady niedyskryminacji ze względu na obywatelstwo.

Po wejściu w życie Traktatu z Maastricht, na którego podstawie do prawa pierwotnego wprowadzone zostało obywatelstwo Unii Europejskiej, podejście Trybunału Sprawiedliwości uległo zasadniczej zmianie. W 2001 roku w wyroku w sprawie Grzelczyk Trybunał stwierdził, że status obywatela Unii ma stanowić podstawowy status obywateli państw członkowskich pozwalający tym spośród nich, którzy znajdują się w takiej samej sytuacji korzystać z takiego samego traktowania wobec prawa bez względu na przynależność państwową, chociaż z zastrzeżeniem wyraźnie przewidzianych wyjątków. Rozstrzygnięcie Trybunału zapadło

18 Wyrok Lair, 39/86, EU:C:1988:322, pkt 15; wyrok Brown, 197/86, EU:C:1988:323, pkt 18. 
w kontekście postępowania przed sądem krajowym dotyczącego odmowy wypłaty zasiłku studentowi, obywatelowi francuskiemu, który studiował w Belgii. Przepisy belgijskie albowiem uprawniały do pobierania zasiłku wyłącznie obywateli belgijskich i mających rzeczywiste miejsce zamieszkania w Belgii. Przypominając rozstrzygnięcie w wyroku Martinez Sala ${ }^{19}$, Trybunał Sprawiedliwości wskazał, że obywatel Unii, który zamieszkuje zgodnie z prawem na terytorium przyjmującego państwa członkowskiego, może powoływać się na zakaz dyskryminacji ze względu na obywatelstwo (ob. art. 18 TFUE) we wszystkich sytuacjach, które wchodzą w zakres ratione materiae prawa wspólnotowego (ob. prawa unijnego). Do takich sytuacji należą przy tym zwłaszcza sytuacje związane z korzystaniem z podstawowych swobód rynku wewnętrznego oraz sytuacje związane z realizacją prawa do przemieszczania się i przebywania na terytorium państw członkowskich $^{20}$. Konsekwencją rozstrzygnięcia w sprawie Grzelczyk było uznanie, że zasada niedyskryminacji ze względu na obywatelstwo obejmuje - w kontekście uprawnień do stypendiów lub innych form pomocy finansowej dla studentów także sytuację obywatela innego państwa członkowskiego, studiującego w państwie przyjmującym.

Jednocześnie w wyroku Grzelczyk Trybunał Sprawiedliwości wyjaśnił modyfikację swojego stanowiska w porównaniu do wydanych kilkanaście lat wcześniej wyroków w sprawach Lair $^{21}$ i Brown ${ }^{22}$. Wskazał w tym zakresie na ustanowienie — na mocy Traktatu z Maastricht modyfikującego traktaty założycielskie — obywatelstwa Unii Europejskiej oraz na wprowadzenie do prawa pierwotnego UE nowych kompetencji w dziedzinie edukacji i kształcenia zawodowego. Biorąc pod uwagę ww. istotne zmiany prawa pierwotnego UE, Trybunał stwierdził, że nie jest dłużej możliwe uznawanie, że kiedy studenci będący obywatelami Unii przenoszą się z jednego państwa członkowskiego do innego państwa członkowskiego w celu odbycia tam studiów, tracą prawa przyznane na mocy traktatu obywatelom UE. Dodatkowo Trybunał wziął pod uwagę, że od czasu wydania wyroku w sprawie Brown uchwalona została dyrektywa 93/96/WE w sprawie prawa pobytu studentów ${ }^{23}$, która także zobowiązywała państwa członkowskie do przyznania prawa pobytu studentom będącym obywatelami państwa członkowskiego, którzy spełniali określone warunki. W konsekwencji okoliczność, że obywatel UE odbywa studia uniwersyteckie w państwie członkowskim przyjmującym (innym niż jego państwo pochodzenia), nie może — zdaniem Trybunału Sprawiedliwości — sama

19 Wyrok Martinez Sala, C-85/96, EU:C:1988:217.

20 Wyrok Grzelczyk, C-184/99, EU:C:2001:458, pkt 32-33.

21 Wyrok Lair, EU:C:1988:322.

22 Wyrok Brown, EU:C:1988:323.

23 Dz. Urz. UE L 317 z dnia 18 grudnia 1993 r., s. 59; Dz. Urz. Polskie wydanie specjalne, rozdz. 6, t. 2, s. 250; została uchylona dyrektywą 2004/38/WE w sprawie prawa obywateli Unii i członków ich rodzin do swobodnego przemieszczania się i pobytu na terytorium Państw Członkowskich, Dz. Urz. UE L 158 z 30.04.3004, s. 77; Dz. Urz. Polskie wydanie specjalne, rozdz. 5, t. 5, s. 46. 
w sobie pozbawić go możliwości powoływania się na zakaz wszelkiej dyskryminacji ze względu na przynależność państwową, wynikający z ob. art. 18 TFUE $^{24}$.

Trybunał potwierdził swoje stanowisko także na gruncie przepisów dyrektywy 2004/38/WE, która uchyliła dyrektywę 93/96/WE. W wyroku Bidar Trybunał przypomniał wyrok Grzelczyk i powtórzył, że dla celów uzyskania pomocy przyznawanej studentom - czy to w formie preferencyjnej pożyczki, czy to w formie stypendium, przeznaczonej na pokrycie kosztów utrzymania — sytuacja obywatela Unii, który przebywa legalnie w innym państwie członkowskim, mieści się w zakresie stosowania Traktatu w rozumieniu ob. art. 18 TFUE $^{25}$. Trybunał dodatkowo zauważył, że ww. ewolucja prawa unijnego znalazła potwierdzenie w art. 24 dyrektywy 2004/38/WE. Zgodnie z nim wszyscy obywatele UE zamieszkujący na podstawie tej dyrektywy na terytorium przyjmującego państwa członkowskiego korzystają z równości traktowania „w zakresie ustanowionym w Traktacie”. Natomiast $\mathrm{z}$ faktu, że w art. 24 ust. 2 tej dyrektywy prawodawca unijny ograniczył przyznawanie pomocy na pokrycie kosztów utrzymania, w formie stypendiów lub pożyczek, studentom, którzy nie nabyli prawa stałego pobytu, Trybunał wywiódł wniosek, że samo przyznawanie tego typu pomocy jest materią, która zgodnie $z$ ust. 1 tego artykułu jest obecnie objęta zakresem stosowania Traktatu ${ }^{26}$.

Dla dopełnienia analizy przepisów prawa UE dotyczących prawa dostępu do stypendiów na pokrycie kosztów studiów należy jeszcze dodać, że pomoc na pokrycie kosztów utrzymania i kształcenia w trakcie studiów jest traktowana jako przywilej socjalny w przypadku, gdy sytuacja danej osoby mieści się w zakresie swobody przepływu pracowników. Jak bowiem wynika z utrwalonego orzecznictwa Trybunału Sprawiedliwości, pomoc na pokrycie kosztów utrzymania i kształcenia w trakcie studiów prowadzących do przyznania tytułu zawodowego stanowi przywilej socjalny w rozumieniu ob. art. 7 ust. 2 rozporządzenia nr 492/2011 w sprawie swobodnego przepływu pracowników wewnątrz Unii ${ }^{27}$ (poprz. art. 7 ust. 2 rozporządzenia 1612/68 w sprawie swobodnego przepływu pracowników wewnątrz Wspólnoty $\left.{ }^{28}\right)^{29}$.

O ile powyższa reguła nie budziła wątpliwości w kontekście sytuacji pracowników migrujących mieszkających w państwie członkowskim przyjmującym oraz ich dzieci, o tyle wątpliwości mogły dotyczyć zastosowania art. 7 ust. 2 rozporządzenia 492/2011 do sytuacji osób - studentów będących dziećmi pracow-

24 Wyrok Grzelczyk, EU:C:2001:458, pkt 34-36.

25 Wyrok Bidar, C-209/03, EU:C:2005:169, pkt 42; wyrok Förster, C-158/07, EU:C:2008:630, pkt 41.

26 Wyrok Bidar, EU:C:2005:169, pkt 43; podobnie w wyroku Förster, EU:C:2008:630, pkt $42-43$ i 48 .

27 Dz. Urz. UE L 141 z dnia 27 maja 2011, s. 1.

28 Dz. Urz. UE L 257 z 19.10.1968, s. 2; Dz. Urz. Polskie wydanie specjalne, rozdz. 5, t. 1, s. 15.

29 Wyrok Lair, EU:C:1988:322, pkt 24; wyrok Bernini, C-3/90, EU:C:1992:89, pkt 23; wyrok Giersch, C-20/12, EU:C:2013:411, pkt 38. 
ników transgranicznych. Taką sytuację analizował Trybunał w sprawie Giersch $i$ in., w której przedmiotem wątpliwości były przepisy luksemburskie, zgodnie z którymi z pomocy finansowej na pobieranie nauki w ramach szkolnictwa mogli skorzystać obywatele Luksemburga lub obywatele innych państw członkowskich przebywający w Luksemburgu jako pracownicy najemni, osoby prowadzące działalność na własny rachunek, osoby zachowujące taki status lub członkowie rodziny jednej z tych osób lub jako osoby, które nabyły prawo stałego pobytu. Sprawa przed sądem krajowym, który następnie skierował do TSUE pytania prejudycjalne, dotyczyła odmowy przyznania takiej pomocy finansowej, z uwagi na to, że osoby ubiegające się o nią co prawda były członkami rodziny pracownika najemnego, lecz nie przebywały w Luksemburgu — ich rodzice bowiem byli pracownikami przygranicznymi (pracowali w Luksemburgu, lecz w nim nie mieszkali).

Trybunał przypomniał wcześniejsze rozstrzygnięcia, z których wynika, że dofinansowywanie studiów dzieci pracowników przez państwo członkowskie stanowi dla pracownika migrującego przywilej socjalny w rozumieniu ob. art. 7 ust. 2 rozporządzenia 2011/492, jeżeli pracownik ten nadal utrzymuje dziecko ${ }^{30}$. Beneficjentami pośrednimi równego traktowania, z którego korzysta pracownik na mocy art. 7 ust. 2 ww. rozporządzenia, są zatem członkowie rodziny pracownika. Skoro przyznanie dziecku pracownika migrującego dofinansowania do studiów stanowi dla tego pracownika migrującego przywilej socjalny, dziecko może samo powoływać się na ten przepis celem uzyskania tego dofinansowania, jeśli na mocy prawa krajowego dofinansowanie to przyznaje się bezpośrednio studentowi ${ }^{31}$.

Podsumowując tę część rozważań, należy stwierdzić, że dostęp do stypendiów i pożyczek studenckich jest kwestią mieszczącą się w zakresie stosowania prawa Unii Europejskiej. Obywatele UE — studenci — w zależności od ich sytuacji będą objęci ochroną na podstawie art. 18 TFUE w związku z art. 21 TFUE (jeżeli mają status niezależny od wykonywania działalności zarobkowej przez nich samych lub ich rodziców) lub też na podstawie przepisów regulujących korzystanie ze swobody przepływu pracowników, w szczególności na podstawie zakazu dyskryminacji w dostępie do przywilejów socjalnych.

\subsection{ZAKRES PRZEDMIOTOWY ZAKAZU DYSKRYMINACJI ZE WZGLĘU NA OBYWATELSTWO W ODNIESIENIU DO DOSTĘPU DO STYPENDIÓW I POŻYCZEK STUDENCKICH}

Podobnie jak w zakresie dostępu do kształcenia wyższego i uniwersyteckiego, tak też w dziedzinie dostępu do stypendiów zakres ochrony przed dyskryminacją ze względu na obywatelstwo początkowo obejmował ochronę przed dyskryminacją bezpośrednią. W omawianym powyżej wyroku Grzelczyk TS uznał, że odmowa

30 Wyrok Bernini, EU:C:1992:89, pkt 29; wyrok Meeusen, C-337/97, EU:C:1999:284, pkt 19; wyrok Giersch, EU:C:2013:411, pkt 39.

31 Wyrok Giersch, EU:C:2013:411, pkt 40. 
wypłacenia zasiłku studentowi będącemu obywatelem innego państwa członkowskiego jedynie na tej podstawie że nie posiada on obywatelstwa państwa wypłacającego świadczenie, stanowi dyskryminację ze względu na obywatelstwo zakazaną na podstawie ob. art. 18 TFUE. Trybunału Sprawiedliwości nie powstrzymała okoliczność, że obowiązywała wówczas dyrektywa 93/96/WE w sprawie prawa pobytu studentów oraz że zgodnie z jej art. 4 prawo pobytu obowiązywało tak długo, jak długo beneficjent spełniał warunki określone w jej art. 1 (w szczególności warunek posiadania wystarczających środków na utrzymanie). Trybunał zważył, że z motywu szóstego preambuły dyrektywy 93/96 wynikało, iż beneficjenci nie powinni stawać się nieuzasadnionym ciężarem dla finansów publicznych państwa przyjmującego. Oznaczało to zatem, że dyrektywa przyznaje pewien stopień solidarności finansowej między obywatelami przyjmującego państwa członkowskiego a obywatelami innych państw członkowskich, zwłaszcza jeżeli trudności, które dany beneficjent napotkał, mają charakter tymczasowy ${ }^{32}$.

Kolejnym krokiem było uznanie w wyroku Bidar, że zasada niedyskryminacji ze względu na obywatelstwo zabrania nie tylko jawnej dyskryminacji ze względu na przynależność państwową, lecz również wszelkich ukrytych form dyskryminacji, które przez stosowanie innych kryteriów rozróżniających powodują de facto ten sam skutek ${ }^{33}$. Zakaz dyskryminacji obejmuje zatem także dyskryminację pośrednią, tzn. takie ukształtowanie przepisów, które co prawda nie różnicują wprost sytuacji obywateli UE i obywateli danego państwa członkowskiego, lecz jednocześnie przez zastosowanie kryterium pozornie neutralnego stawiają w gorszej sytuacji studentów z innych państw członkowskich.

Takim kryterium, pozornie neutralnym, jest w szczególności wymóg posiadania miejsca zamieszkania w państwie członkowskim wypłacającym stypendium lub udzielającym pożyczki studenckiej. Trybunał Sprawiedliwości analizował takie przepisy w sprawie Bidar. Sąd krajowy kierujący pytanie prejudycjalne do Trybunału Sprawiedliwości rozpatrywał sytuację obywatela francuskiego, który mieszkał w Zjednoczonym Królestwie. Danny Bidar przed rozpoczęciem studiów zamieszkiwał trzy lata w Wielkiej Brytanii, gdzie ukończył szkołę średnią. Kiedy podjął studia w Londynie, wystąpił o udzielenie pożyczki studenckiej na sfinansowanie nauki. Tymczasem, zgodnie z przepisami krajowymi, pożyczkę studencką mogła otrzymać osoba, która zamieszkiwała w tym państwie oraz osiedliła się w rozumieniu przepisów krajowych — tzn. zamieszkiwała w tym państwie przez trzy lata poprzedzające rozpoczęcie studiów. Jednocześnie jednak przepisy były tak ukształtowane, że student nie mógł nigdy uzyskać statusu osoby osiedlonej w rozumieniu przepisów krajowych.

Trybunał Sprawiedliwości stwierdził, że wymogi, aby ubiegający się o pomoc osiedlił się państwie przyjmującym (w rozumieniu prawa krajowego) oraz za-

32 Wyrok Grzelczyk, EU:C:2001:458, pkt 44.

33 Wyrok Bidar, EU:C:2005:169, pkt 51. 
mieszkiwał na terytorium tego państwa członkowskiego przyjmującego przez trzy lata w okresie poprzedzającym studia, mogą być łatwiej spełnione przez obywateli tego państwa, które udziela pożyczki, niż przez obywateli innych państw członkowskich. Przepisy takie stawiają zatem obywateli innych państw członkowskich w gorszej sytuacji niż obywateli tego państwa. Taka dyskryminacja pośrednia może być uznana za uzasadnioną, jeżeli zróżnicowanie opiera się na obiektywnie uzasadnionych przesłankach niezależnych od przynależności państwowej zainteresowanych osób oraz jest proporcjonalne do uzasadnionego celu realizowanego przez prawo krajowe ${ }^{34}$.

Trybunał przyznał, że uzasadnieniem dyskryminacji pośredniej w zakresie udzielania pożyczek studenckich może być zamiar państwa członkowskiego do przyznania tej formy pomocy jedynie takim studentom, którzy wykażą określony stopień zintegrowania ze społeczeństwem tego państwa. Zastrzegł jednocześnie, że państwa te nie mogą wymagać od zainteresowanych studentów, aby związali się z jego rynkiem pracy. Albowiem skoro wiedza zdobyta przez studenta podczas studiów wyższych nie przesądza o przypisaniu go co do zasady do danego geograficznego rynku pracy, sytuacja studenta ubiegającego się o pomoc przeznaczoną na pokrycie kosztów utrzymania nie jest porównywalna z sytuacją wnioskodawcy ubiegającego się o zasiłek dla młodych poszukujących pierwszej pracy lub zasiłek na poszukiwanie pracy ${ }^{35}$.

Zdaniem Trybunału można natomiast uznać, że osoba jest do pewnego stopnia zintegrowana z państwem członkowskim przyznającym pomoc, jeżeli mieszkała ona w tym państwie przez pewien okres, na przykład przez trzy lata — tak jak to miało miejsce w przypadku Danny'ego Bidara. Z tego względu za niedopuszczalny uznał Trybunał warunek „osiedlenia się” (w rozumieniu prawa krajowego) w Zjednoczonym Królestwie, z wyłączeniem możliwości uzyskania przez studenta statusu osoby, która się osiedliła. Konsekwencją takiego przepisu jest bowiem to, że student będący obywatelem innego państwa członkowskiego, przebywający legalnie w przyjmującym państwie członkowskim, gdzie przy tym zdobył znaczną część swojego średniego wykształcenia — przez co w sposób rzeczywisty związał się ze społeczeństwem tego państwa, nie może kontynuować nauki na tych samych warunkach, co znajdujący się w tej samej sytuacji student będący obywatelem tego państwa członkowskiego ${ }^{36}$.

Konsekwencją wyroku Bidar jest upoważnienie państw członkowskich do ograniczania kręgu beneficjentów systemu stypendiów lub pożyczek studenckich jedynie do takich osób, które wykazują wystarczający stopień integracji ze społeczeństwem państwa oferującego takie stypendia lub pożyczki. Zatem dyskryminacja pośrednia, uzależniająca uzyskanie stypendium lub pożyczki od wymo-

\footnotetext{
34 Ibidem, pkt 53-54.

35 Ibidem, pkt 57-58.

${ }^{36}$ Ibidem, pkt 60-62.
} 
gu zamieszkiwania przez pewien czas na terytorium tego państwa, które takie stypendium lub pożyczkę oferuje, może być uznana za dopuszczalną w świetle prawa UE. Prowadzi to jednak do istotnego zróżnicowania zakresu podmiotowego zakazu dyskryminacji ze względu na obywatelstwo, o czym będzie mowa niżej.

Na razie, tytułem uzupełnienia, należy dodać, że podejście podobne do tego zawartego w wyroku Bidar przyjął Trybunał, analizując uzależnienie uzyskania pomocy finansowej na pobieranie nauki w ramach szkolnictwa wyższego od zamieszkiwania w państwie członkowskim wypłacającym tę pomoc w świetle przepisów regulujących swobodę przepływu pracowników, w szczególności w świetle art. 7 ust. 2 rozporządzenia 492/2011. W sprawie Giersch sąd krajowy rozpatrujący sprawę główną uznał, że wymóg, by osoby ubiegające się o taką pomoc posiadały miejsce zamieszkania w Luksemburgu, prowadzi do zróżnicowania traktowania dwóch kategorii osób: tych zamieszkujących w danym państwie oraz tych, które chociaż w nim nie zamieszkują, to jednak są dziećmi pracowników przygranicznych, pracujących w państwie przyznającym pomoc. Trybunał potwierdził także na gruncie art. 45 TFUE i art. 7 ust. 2 rozporządzenia 1612/68 (ob. rozporządzenia 492/2011), że przepisy te zabraniają nie tylko jawnej dyskryminacji ze względu na przynależność państwową, lecz również wszelkich ukrytych form dyskryminacji, które przez stosowanie innych kryteriów rozróżniających powodują de facto ten sam skutek ${ }^{37}$. Trybunał uznał, że przepisy krajowe przewidują rozróżnienie oparte na zamieszkaniu, które może działać na niekorzyść obywateli innych państw członkowskich, ponieważ nierezydentami są najczęściej obcokrajowcy ${ }^{38}$. Dla powyższego rozstrzygnięcia nie miało znaczenia to, że przepis sporny dotyczył zarówno obywateli tego państwa, jak i obywateli innych państw członkowskich. Jak wynika bowiem z utrwalonego orzecznictwa TSUE, aby przepis mógł być zakwalifikowany jako pośrednio dyskryminujący, nie jest konieczne, by skutkował on uprzywilejowaniem wszystkich obywateli danego państwa lub stawianiem w niekorzystnym położeniu jedynie obywateli innych państw członkowskich, z wyjątkiem własnych obywateli ${ }^{39}$.

Dalszy tok wywodów Trybunału Sprawiedliwości jest podobny do toku rozumowania zastosowanego w wyroku Bidar na gruncie art. 18 TFUE, podkreślono bowiem w wyroku konieczność wykazania, że nierówne traktowanie było obiektywnie uzasadnione i proporcjonalne do zamierzonego celu. Trybunał zaakceptował deklarowany przez rząd Luksemburga w tej sprawie cel, którym było zapewnienie wysokiego poziomu wykształcenia ludności zamieszkującej na jej terytorium oraz wspieranie rozwoju gospodarki, uznając, że taki cel może uzasadniać dyskryminację pośrednią ze względu na przynależność państwo-

37 Wyrok Giersch, EU:C:2013:411, pkt 41 i cytowane tam orzecznictwo oraz pkt 46.

38 Ibidem, pkt 44 i cytowane tam orzecznictwo.

39 Ibidem, pkt 45 i cytowane tam orzecznictwo. 
wą $^{40}$. Ostatecznie jednak uznał, że przepisy krajowe wykraczają poza to, co konieczne do osiągnięcia prawnie uzasadnionego celu polegającego na zwiększeniu wśród mieszkańców liczby posiadaczy dyplomów ukończenia studiów w celu wspierania rozwoju gospodarki krajowej ${ }^{41}$.

Analizując zakres przedmiotowy zakazu dyskryminacji ze względu na obywatelstwo, należy jeszcze zwrócić uwagę na obowiązujący art. 24 dyrektywy 2004/38/WE. Na podstawie art. 24 ust. 1 dyrektywy potwierdzono obowiązywanie zakazu dyskryminacji ze względu na obywatelstwo, który wynika wprost z art. 18 TFUE. Jednocześnie, na mocy art. 24 ust. 2 tej dyrektywy przewidziano odstępstwo od zasady niedyskryminacji ze względu na obywatelstwo. Zgodnie bowiem z tym przepisem przyjmujące państwo członkowskie nie jest zobowiązane m.in. do udzielania pomocy na pokrycie kosztów utrzymania w czasie studiów, włącznie z kształceniem zawodowym, w postaci stypendiów lub pożyczek studenckich dla osób niebędących pracownikami najemnymi, osób pracujących na własny rachunek, osób, które zachowują ten status i członków ich rodzin.

W konsekwencji zasada niedyskryminacji ze względu na obywatelstwo, wynikająca $\mathrm{z}$ art. 18 TFUE, doznaje ograniczenia wynikającego $\mathrm{z}$ art. 24 ust. 2 dyrektywy 2004/18/WE. Należy jednak podkreślić, że aby zminimalizować ten ograniczający skutek dyrektywy 2004/38/WE, Trybunał Sprawiedliwości wymaga, by użyte w art. 24 ust. 2 dyrektywy 2004/38/WE sformułowanie „stypendia i pożyczki..." interpretować restrykcyjnie. W wyroku Komisja p. Austrii (C-75/11) Trybunał stwierdził, że ww. przepis dyrektywy, jako odstępstwo od zasady równego traktowania wyrażonej w art. 18 TFUE (i której to zasady art. 24 ust. 1 stanowi jedynie szczególny wyraz), powinien być interpretowany w sposób ścisły. Chociaż ulgi w opłatach za przejazdy przyznawane studentom stanowią pomoc na ich utrzymanie, to jedynie pomoc na pokrycie kosztów utrzymania w czasie studiów „w postaci stypendiów lub pożyczek studenckich" wchodzi w zakres wyjątku przewidzianego w art. 24 ust. 2 dyrektywy 2004/38/WE. Zdaniem Trybunału każda inna wykładnia tego przepisu byłaby sprzeczna z jego brzmieniem oraz z obowiązkiem dokonywania wykładni tego przepisu w zgodnie z postanowieniami Traktatów, w tym dotyczącymi obywatelstwa ${ }^{42}$. W konsekwencji państwa członkowskie mogą ograniczać dostęp do pomocy finansowej dla studentów, przyznając taką pomoc jedynie tym osobom, które wykazują więź. Zakres przedmiotowy różnicowania jest jednak ograniczony jedynie do pomocy w formie stypendiów i pożyczek, natomiast zróżnicowanie nie może dotyczyć innych form pomocy, takich jak właśnie ulgi w przejazdach.

\footnotetext{
40 Ibidem, pkt 56.

41 Ibidem, pkt 82.

42 Wyrok Komisja p. Austrii, C-75/11, EU:C:2012:605, pkt 54-56.
} 
3.3. ZAKRES PODMIOTOWY ZAKAZU DYSKRYMINACJI ZE WZGLĘDU NA OBYWATELSTWO W ODNIESIENIU DO DOSTĘPU DO STYPENDIÓW I POŻYCZEK STUDENCKICH

W zakresie dostępu do stypendiów i pożyczek studenckich prawo Unii Europejskiej przewiduje różny zakres ochrony w zależności od sytuacji indywidualnej danej osoby. Jak wskazano powyżej, wyraźnie potwierdza to art. 24 ust. 1 i 2 dyrektywy 2004/38/WE.

W konsekwencji grupą uprzywilejowaną, której przysługuje ochrona przed dyskryminacją ze względu na obywatelstwo, są osoby aktywne zawodowo, tzn. będące pracownikami migrującymi, osobami prowadzącymi działalność na własny rachunek, osobami które zachowują ten status lub są członkami rodziny takich osób. Z wyroku Giersch wynika ponadto, że ten uprzywilejowany status przysługuje także pracownikom przygranicznym i członkom ich rodzin. Trybunał w tej sprawie analizował wymóg zamieszkania jako warunek uzyskania pomocy na naukę w kontekście sytuacji dzieci pracowników przygranicznych. Zaakceptował co prawda uzasadnienie pośredniej dyskryminacji przedstawione przez rząd luksemburski, który wskazał, że przepisy krajowe wprowadzające wymóg zamieszkania mają na celu zapewnienie wysokiego poziomu wykształcenia ludności zamieszkującej na jego terytorium oraz wspieranie rozwoju gospodarki. Analizując jednak proporcjonalność tych działań, Trybunał uznał, że system stworzony na podstawie przepisów tego państwa członkowskiego miał charakter zbyt wykluczający, wymagał bowiem spełnienia warunku wcześniejszego zamieszkania studenta na terytorium danego państwa członkowskiego i w ten sposób uprzywilejowywał element, który niekoniecznie był jedynym elementem reprezentatywnym dla stwierdzenia rzeczywistego stopnia powiązania zainteresowanego z tym państwem członkowskim. Istnienie racjonalnego prawdopodobieństwa, że beneficjenci pomocy wrócą do tego państwa członkowskiego, by się w nim osiedlić i uczestniczyć w rynku pracy w celu przyczyniania się do jego rozwoju gospodarczego, mogło być — zdaniem Trybunału - wykazane za pomocą elementów innych niż wymóg spełnienia przez danego studenta warunku uprzedniego zamieszkania. Takie prawdopodobieństwo można byłoby wywodzić z faktu, że student ten zamieszkuje sam lub z rodzicami w jednym z państw członkowskich graniczących z Luksemburgiem oraz z tego, że jego rodzice od długiego czasu pracują w tym państwie i mieszkają w jego okolicy ${ }^{43}$.

W odniesieniu do innych studentów, którzy jednocześnie nie są pracownikami migrującymi, osobami korzystającymi ze swobody przedsiębiorczości, nie są także członkami rodziny zależnymi od obywatela UE korzystającego ze swobody przemieszczania się na podstawie swobody przepływu pracowników lub przedsiębiorczości, wywodzących swoje uprawnienia bezpośrednio ze swobody przemieszczania się (art. 21 TFUE) i zasady niedyskryminacji ze względu na

43 Szerzej por. wyrok Giersch, EU:C:2013:411, pkt 63-66. 
obywatelstwo (art. 18 TFUE), państwa członkowskie mogą ograniczyć dostęp do stypendiów lub pożyczek studenckich, w szczególności oferując je wyłącznie osobom wykazującym pewien stopień integracji ze społeczeństwem tego państwa, które wypłaca świadczenia. Taki wniosek płynie zarówno z wyroku Bidar, w którym interpretowano art. 18 TFUE, jak również z wyroku Giersch, w którym przedmiotem analizy był art. 45 TFUE oraz rozporządzenie 492/2011. Istotne jest zatem wyjaśnienie, jakie są dopuszczalne metody ustalania, że osoba ubiegająca się o stypendium lub pożyczkę wykazuje wystarczający stopień integracji z danym państwem członkowskim.

Doprecyzowania kwestii, jakie warunki są dopuszczalne w celu wykazania więzi, dokonał Trybunał w sprawie Förster, w której przedmiotem analizy był ustanowiony w prawie krajowym — jako warunek uzyskania stypendium wymóg zamieszkiwania nieprzerwanie przez pięć lat przed ubieganiem się o tę pomoc. Trybunał stwierdził, że warunek taki jest odpowiednim środkiem do zapewnienia, że osoba wnioskująca o przyznanie stypendium na pokrycie kosztów utrzymania jest zintegrowana w ramach przyjmującego państwa członkowskiego $^{44}$. Analizując proporcjonalność tego wymogu, Trybunał wskazał, że warunek zamieszkiwania w sposób nieprzerwany przez pięć lat nie może zostać uznany za zbyt uciążliwy, biorąc pod uwagę wymogi dotyczące stopnia integracji w ramach państwa członkowskiego przyjmującego. Jednocześnie Trybunał zwrócił uwagę na przywołany wyżej art. 24 ust. 2 dyrektywy 2004/38/WE, który, chociaż nie miał zastosowania do okoliczności faktycznych w sprawie głównej, to jednak stanowił wskazówkę dla Trybunału ${ }^{45}$.

Trybunał Sprawiedliwości z jednej strony interpretuje szeroko zakaz dyskryminacji ze względu na obywatelstwo, uznając że zakaz ten obejmuje zarówno dyskryminację bezpośrednią, jak również pośrednią. Z drugiej strony jednak akceptuje stanowisko państw członkowskich, które dążą do ograniczania kręgu osób uprawnionych do stypendiów i pożyczek studenckich w ten sposób, by przyznawać je jedynie osobom wykazującym więź ze społeczeństwem tego państwa, które stypendia lub pożyczki oferuje.

Nietrudno jest zauważyć, że stanowisko Trybunału Sprawiedliwości w odniesieniu do możliwości pozbawienia migrujących studentów prawa do stypendiów lub pożyczek, którzy nie wykazują wystarczającej więzi ze społeczeństwem państwa oferującego świadczenia, jest spójne ze stanowiskiem w odniesieniu do innych obywateli UE, którzy w niewystarczający sposób uczestniczą w życiu gospodarczym UE — chodzi o takie sprawy jak Brey, Dano i Alimanowicz. W tym znaczeniu orzecznictwo TSUE dotyczące studentów ,zainfekowało” sytuację innych kategorii obywateli UE przemieszczających się w UE.

44 Wyrok Förster, EU:C:2008:630, pkt 52.

45 Ibidem, pkt 55. 
5. DOSTĘP DO STYPENDIÓW NA STUDIA ZA GRANICĄ — NOWY WYMIAR SWOBODY PRZEMIESZCZANIA SIĘ STUDENTÓW

\subsection{DOSTĘP DO STYPENDIÓW NA STUDIA ZA GRANICĄ JAKO KWESTIA OBJĘTA ZAKRESEM PRAWA UE}

Oprócz wspierania studentów studiujących w danym państwie członkowskim państwa wspierają również mobilność swoich obywateli, oferując im stypendia lub pożyczki na studia w innych państwach członkowskich i jednocześnie starając się ograniczyć krąg osób uprawnionych do tych świadczeń. Przede wszystkim jednak należy podkreślić, że prawo Unii Europejskiej nie wymaga od państw członkowskich wprowadzania takich stypendiów lub pożyczek. Jak wskazano na samym początku niniejszego opracowania, kompetencje Unii Europejskiej w dziedzinie edukacji mają charakter wspierający i uzupełniający, zatem prawo UE nie może państwom członkowskim narzucać takiego obowiązku. Dopiero kiedy państwo członkowskie, korzystając z przysługujących mu nadal kompetencji w zakresie organizacji swojego systemu kształcenia, zdecyduje o wprowadzeniu systemu stypendiów lub pożyczek na finansowanie studiów w innych państwach członkowskich lub poza granicami Unii Europejskiej, mogą aktualizować się obowiązki wynikające $\mathrm{w}$ istocie $\mathrm{z}$ bezpośrednio skutecznych przepisów Traktatu o funkcjonowaniu Unii Europejskiej. Zatem dopiero wtedy powstaje pytanie, czy w zakres prawa Unii Europejskiej wchodzi sytuacja obywatela UE, który zostałby pozbawiony przez jego własne państwo, którego obywatelstwo posiada, prawa do takiego stypendium na studia za granicą.

Kwestię tę rozstrzygnął Trybunał Sprawiedliwości po raz pierwszy w wyroku Morgan i Bucher. Sądy niemieckie, które skierowały pytania prejudycjalne do TSUE, rozpatrywały skargi obywatelek niemieckich ubiegających się o stypendia od państwa niemieckiego na pokrycie kosztów studiów w innych państwach członkowskich. Jednakże przepisy niemieckie regulujące przyznawanie tych stypendiów uzależniały ich otrzymanie od spełnienia warunku, by studia za granicą stanowiły kontynuację edukacji w niemieckiej placówce edukacyjnej trwającej co najmniej rok.

Trybunał Sprawiedliwości wskazał, że jako obywatelki niemieckie panie Morgan i Bucher korzystają ze statusu obywateli Unii i mogą powoływać się na prawa wynikające $\mathrm{z}$ posiadania tego statusu również wobec swojego państwa pochodzenia. Zdaniem Trybunału do sytuacji wchodzących w zakres stosowania prawa UE wchodzą przypadki wykonywania podstawowych swobód gwarantowanych traktatami, w szczególności swobody przemieszczania się i pobytu na terytorium państw członkowskich, tym bardziej że prawo do stypendium rozpatrywane w sprawach głównych dotyczyło właśnie studiów odbywanych w innym państwie członkowskim ${ }^{46}$. Zdaniem Trybunału państwa członkowskie zachowują

46 Wyrok Morgan i Bucher, C-11/06 i C-12/06, EU:C:2007:626, pkt 22-23; wyrok Prinz i Seeberger, C-523/11 i C-585/11, EU:C:2013:524, pkt 25; wyrok Meneses, C-220/12, EU:C:2013:683, 
kompetencje przysługujące im na podstawie ob. art. 165 ust. 1 TFUE w zakresie treści nauczania i organizacji ich systemów edukacyjnych. Przypomniał jednak wynikający w tym zakresie z utrwalonego orzecznictwa warunek, że kompetencje te powinny być wykonywane zgodnie z prawem unijnym, a w szczególności postanowieniami traktatu dotyczącymi swobody przemieszczania się i pobytu na terytorium państw członkowskich przyznanej na mocy ob. art 21 ust. 1 TFUE ${ }^{47}$.

Dodatkowo Trybunał podkreślił, że prawo Unii nie nakłada na państwa członkowskie żadnego obowiązku ustanowienia systemu pomocy finansowej na pokrycie kosztów studiów w innym państwie członkowskim lub poza granicami UE. Jeżeli jednak państwo członkowskie ustanawia system umożliwiający osobom uczącym się skorzystanie z takiej pomocy, musi zapewnić, aby zasady jej przyznawania w sposób nieuzasadniony nie ograniczały prawa do przemieszczania się i pobytu na terytorium państw członkowskich ${ }^{48}$.

Stypendium lub pożyczka studencka związana z odbywaniem studiów w innych państwach członkowskich może także wchodzić w zakres pojęcia korzyści socjalnej w rozumieniu art. 7 ust. 2 rozporządzenia 492/2011 w sytuacji, gdy ubiega się o nie student będący członkiem rodziny pracownika migrującego. Taki wniosek płynie z rozstrzygnięcia Trybunału Sprawiedliwości w wyroku Komisja p. Niderlandom (C-542/09), w której przedmiotem analizy były przepisy krajowe przewidujące m.in. jako warunek uzyskania stypendium na finansowanie studiów w innym niż Niderlandy państwie członkowskim wymóg legalnego zamieszkiwania przez co najmniej trzy lata na przestrzeni sześciu lat poprzedzających przyjęcie na studia (zasada 3 z 6). Przepisy te uniemożliwiały uzyskanie stypendium dzieciom pracowników przygranicznych, którzy pracowali w Niderlandach, lecz ani oni, ani ich dzieci nie zamieszkiwali w tym państwie członkowskim.

Warto w tym kontekście zauważyć, że w świetle wyroku Morgan i Bucher tak skonstruowane przepisy z pewnością wchodziłyby w zakres prawa UE z uwagi na to, że dotyczyły także obywateli niderlandzkich, którzy nie zamieszkiwali w tym państwie. Ze względu jednak na fakt, że skarga Komisji opierała się na naruszeniu art. 7 ust. 2 rozporządzenia 492/2011, Trybunał Sprawiedliwości dokonał interpretacji tego właśnie przepisu rozporządzenia. Przypomniał przede wszystkim utrwalone orzecznictwo, z którego wynika, że stypendium na pokrycie kosztów utrzymania i szkolenia w trakcie studiów prowadzących do przyznania tytułu za-

pkt 19-20; wyrok Elrick, C-275/12, EU:C:2013:684, pkt 19-20; wyrok Martens, C-359/13, EU:C:2015:118, pkt 22.

47 Wyrok Morgan i Bucher, EU:C:2007:626, pkt 24 oraz cytowane tam orzecznictwo; a także wyrok Prinz i Seeberger, EU:C:2013:524, pkt 26; wyrok Meneses, EU:C:2013:683, pkt 21; wyrok Elrick, EU:C:2013:684, pkt 21; wyrok Martens, EU:C:2015:118, pkt 23.

48 Wyrok Morgan i Bucher, EU:C:2007:626, pkt 28; wyrok Prinz i Seeberg, EU:C:2013:524, pkt 30; wyrok Meneses, EU:C:2013:683, pkt 25; wyrok Martens, EU:C:2015:118, pkt 24. 
wodowego stanowi przywilej socjalny w rozumieniu art. 7 ust. 2 rozporządzenia $492 / 2011^{49}$.

Wydaje się, że ostatnim ogniwem, którego jak dotąd brakuje w tym obszarze, jest ustalenie, czy w zakres stosowania prawa Unii Europejskiej wchodziłaby sytuacja obywatela UE ubiegającego się o stypendium lub pożyczkę w państwie zamieszkania, którego obywatelstwa nie posiada, w związku z podjęciem studiów w trzecim państwie członkowskim. Wydaje się, że taka sytuacja także wchodziłaby w zakres prawa UE z uwagi na skorzystanie przez taką osobę ze swobody przemieszczania się. Innymi słowy, skoro taka osoba skorzystała już wcześniej ze swobody przemieszczania się i zamieszkała w państwie członkowskim innym niż państwo, którego obywatelstwo posiada, wówczas także powinna ona korzystać z ochrony przyznanej przez prawo UE, w szczególności w zakresie niedyskryminacyjnego traktowania.

\subsection{ZAKRES PRZEDMIOTOWY UPRAWNIEŃ W ZAKRESIE DOSTĘPU DO STYPENDIÓW NA STUDIA ZA GRANICĄ}

Po pierwsze, z prawa Unii Europejskiej wynika uprawnienie do ochrony przed ograniczeniami w swobodzie przemieszczania się i pobytu, gwarantowanej na podstawie art. 21 ust. 1 TFUE. Trybunał Sprawiedliwości w odniesieniu do studentów, którzy chcieliby wyjechać do innego państwa członkowskiego (lub za granice Unii Europejskiej) w celu odbycia tam studiów odnosi swoje wcześniejsze utrwalone orzecznictwo, zgodnie z którym uregulowanie krajowe, które stawia w mniej korzystnej sytuacji własnych obywateli z tego tylko powodu, że korzystają oni ze swobody przemieszczania się i pobytu w innym państwie członkowskim, stanowi ograniczenie swobód gwarantowanych na mocy ob. art. 21 ust. 1 TFUE każdemu obywatelowi Unii. Co za tym idzie - przyznane przez traktat uprawnienia do swobodnego przemieszczania się nie byłyby w pełni skuteczne, gdyby obywatel państwa członkowskiego mógł zostać powstrzymany od korzystania z nich przez przeszkody dotyczące jego pobytu w innym państwie członkowskim ustanowione przez przepisy prawne państwa członkowskiego jego pochodzenia, które powodują zaistnienie niekorzystnej dla niego sytuacji, jeżeli z nich skorzysta ${ }^{50}$. Trybunał podkreślił, że powyższe stanowisko jest szczególnie istotne w dziedzinie edukacji, jeżeli weźmie się pod uwagę jeden z celów Unii, tzn. sprzyjanie mobilności studentów i nauczycieli (ob. art. 165 ust. 2 tiret drugie TFUE). Zatem jeżeli państwo członkowskie ustanawia system stypendiów edukacyjnych umożliwiający osobom uczącym się korzystanie z nich w sytuacji, w której odbywają kształcenie w innym państwie członkowskim, to musi zapewnić, aby zasady przyznawania tej pomocy

49 Wyrok Komisja p. Niderlandom, C-542/09, EU:C:2012:346, pkt 34-36.

50 Wyrok Morgan i Bucher, EU:C:2007:626, pkt 25-26 oraz cytowane tam orzecznictwo; wyrok Prinz i Seeberger, EU:C:2013:524, pkt 27-28; wyrok Meneses, EU:C:2013:683, pkt 22-23; wyrok Elrick, EU:C:2013:684, pkt 22-23; wyrok Martens, EU:C:2015:118, pkt 25-26. 
nie tworzyły nieuzasadnionych ograniczeń w zakresie prawa do przemieszczania się i pobytu na terytorium państw członkowskich ${ }^{51}$.

W wyroku Morgan i Bucher Trybunał Sprawiedliwosci uznał, że warunek uprzedniego odbycia co najmniej rocznych studiów w Niemczech, przed ubieganiem się o stypendium na studia za granicą, stanowi ograniczenie swobody przemieszczania się i pobytu gwarantowanej na mocy art. 21 TFUE. Może on bowiem powodować osobiste niedogodności, dodatkowe koszty i ewentualne opóźnienia, z jakimi się łączy, a w konsekwencji może zniechęcać obywateli Unii do wyjazdu ze swego państwa pochodzenia $\mathrm{w}$ celu pobierania nauki w innym państwie członkowskim i skorzystania tym samym ze swobody przemieszczania się i pobytu, przyznanej na podstawie art. 21 ust. $1^{52}$.

Z kolei w wyroku Prinz i Seeberg Trybunał uznał, że ograniczeniem swobody przemieszczania się i pobytu jest warunek nieprzerwanego zamieszkania przez okres trzech lat, nawet jeżeli ma zastosowanie w sposób niezróżnicowany do obywateli niemieckich i innych obywateli Unii. Ograniczenie to może bowiem zniechęcać obywateli danego państwa członkowskiego do skorzystania ze swobody przemieszczania się z uwagi na skutki, jakie owo skorzystanie ze swobody może mieć dla ich prawa do stypendium edukacyjnego ${ }^{53}$.

W wyroku Meneses zaś Trybunał uznał, że ograniczeniem swobody przemieszczania się i pobytu jest ustalony dla obywateli niemieckich warunek uzyskania stypendium w postaci posiadania stałego miejsca pobytu w państwie, w którym dana osoba uczęszcza do placówki edukacyjnej lub jeżeli udaje się z państwa stałego miejsca pobytu do państwa sąsiedniego. Tymczasem Meneses, obywatel niemiecki, posiadał stałe miejsce pobytu w Turcji, lecz chciał studiować w Niderlandach (a nie w Turcji ani w żadnym sąsiadującym z nią państwie). W tym przypadku Trybunał także uznał, że warunek taki stanowi ograniczenie swobody przemieszczania się i pobytu, z której obywatele korzystają na mocy art. 21 TFUE, ponieważ przepis taki może zniechęcać obywateli Unii do skorzystania ze swobody przemieszczania się i pobytu w innym państwie członkowskim z uwagi na skutki, jakie skorzystanie z tej swobody może mieć dla ich prawa do pomocy na kształcenie ${ }^{54}$.

Podobnie w wyroku Elrick Trybunał Sprawiedliwości stwierdził, że stanowi ograniczenie swobody przemieszczania się przepis krajowy, który wiąże przyznanie pomocy na kształcenie za granicą z warunkiem równoważności z kształceniem

51 Wyrok Morgan i Bucher, EU:C:2007:626, pkt 27-28; wyrok Prinz i Seeberger, EU:C:2013:524, pkt 29-30; wyrok Meneses, EU:C:2013:683, pkt 24-25; wyrok Elrick, EU:C:2013:684, pkt 24-25; wyrok Martens, EU:C:2015:118, pkt 27.

52 Wyrok Morgan i Bucher, EU:C:2007:626, pkt 30-31.

53 Wyrok Prinz i Seeberger, EU:C:2013:524, pkt 31-32.

54 Ibidem, pkt 28. 
odbywanym w klasach szkół zawodowych prowadzącym do uzyskania dyplomu zawodowego po odbyciu co najmniej dwuletniego kursu ${ }^{55}$.

Wreszcie w wyroku Martens Trybunał uznał, że ograniczeniem swobody przemieszczania się jest przepis uzależniający wypłacanie pomocy finansowej na pokrycie kosztów studiów za granicą od spełnienia warunku, by osoba ta zamieszkiwała w danym państwie członkowskim przez co najmniej trzy lata w okresie sześciu lat poprzedzających rozpoczęcie studiów. Przepis taki bowiem może stawiać w niekorzystnej sytuacji osobę wnioskującą o przyznanie takiej pomocy z tego tylko powodu, że skorzystała z prawa do swobodnego przemieszczania się i pobytu w innym państwie członkowskim, zważywszy na skutki, jakie skorzystanie przez nią z tej swobody może mieć na możliwości otrzymania tej pomocy ${ }^{56}$.

Tego rodzaju ograniczenia swobody przemieszczania się i pobytu, które dane państwo członkowskie stwarza swoim własnym obywatelom, mogą być uzasadnione jedynie wówczas, gdy są oparte na obiektywnych przesłankach interesu ogólnego, niezwiązanych z przynależnością państwową osób, których dotyczą, i proporcjonalne do słusznego celu, jaki realizuje prawo krajowe, przy czym środek można uznać za proporcjonalny, jeżeli jest zdatny do osiągnięcia zamierzonego celu i nie wykracza poza to, co jest konieczne do jego osiągnięcia ${ }^{57}$.

W wyroku Morgan i Bucher Trybunał nie zaakceptował jednak żadnego z argumentów przedstawianych przez sąd odsyłający oraz rządy państw członkowskich, które przedstawiły uwagi w tej sprawie ${ }^{58}$. W szczególności Trybunał analizował uzasadnienie opierające się na konieczności zapobiegania sytuacji, w której wypłacanie tych stypendiów stałoby się nadmiernym obciążeniem finansowym dla danego państwa członkowskiego. W tym względzie Trybunał przypomniał swoje stanowisko odnośnie do przyznawania stypendiów studentom, którzy przyjeżdżają do danego państwa z innych państw członkowskich w wyroku Bidar, w którym stwierdził, że dopuszczalne jest zapobieganie sytuacji, gdy przyznawanie pomocy na pokrycie kosztów utrzymania studentów pochodzących z innych państw członkowskich stałoby się nadmiernym obciążeniem, które mogłoby mieć konsekwencje dla całego systemu pomocy, jaka może zostać przyznana przez to państwo. W tym

55 Wyrok Elrick, EU:C:2013:684, pkt 28-29.

56 Wyrok Martens, EU:C:2015:118, pkt 31.

57 Wyrok Morgan i Bucher, EU:C:2007:626, pkt 33 oraz cytowane tam orzecznictwo; wyrok Prinz i Seeberger, EU:C:2013:524, pkt 33; wyrok Meneses, EU:C:2013:683, pkt 29; wyrok Elrick, EU:C:2013:684, pkt 30; wyrok Martens, EU:C:2015:118, pkt 34.

58 Tzn. dążenie do zapewnienia, że stypendium edukacyjne zostanie przyznane tylko tym studentom, których zdolności pozwolą im na ukończenie nauki (pkt 35 wyroku); dążenie do umożliwienia osobom uczącym się sprawdzenia, czy dokonały dobrego wyboru kierunku studiów (pkt 37 wyroku); promowanie pobierania nauki w państwach członkowskich innych niż Republika Federalna Niemiec (pkt 40 wyroku); konieczność ograniczenia nadmiernego obciążenia dla budżetu państwa (pkt 42 wyroku); konieczność zapobiegania — w braku systemu koordynacji pomocy udzielanej na kształcenie między państwami członkowskimi — ryzyku kumulacji świadczeń pobieranych od różnych państw członkowskich (pkt 47 wyroku). 
celu dopuszczalne jest ograniczenie pomocy do tych studentów, którzy wykażą określony stopień zintegrowania ze społeczeństwem tego państwa. Także w przypadku stypendiów przyznawanych własnym obywatelom na studia za granicą, jeżeli istnieje ryzyko takiego nadmiernego obciążenia, to podobne rozważania mogą znajdować zastosowanie odnośnie do przyznawania przez państwo członkowskie stypendiów edukacyjnych osobom uczącym się, które chciałyby odbyć kształcenie w innych państwach członkowskich ${ }^{59}$. Zdaniem Trybunału jednak w tym przypadku warunek odbycia przynajmniej rocznego kształcenia na studiach wyższych w państwie pochodzenia ma charakter zbyt ogólny i wyłączny w tym zakresie. Uprzywilejowuje on w sposób niesłuszny jedną okoliczność, która może nie być reprezentatywna dla rzeczywistego stopnia powiązania osoby ze społeczeństwem tego państwa członkowskiego w momencie ubiegania się o stypendium. Warunek ten wykracza tym samym poza zakres konieczny do osiągnięcia zamierzonego celu i nie może być uznany za proporcjonalny ${ }^{60}$.

Podobnie w wyroku Prinz $i$ Seeberg Trybunał zaakceptował co do zasady uzasadnienie takiego ograniczenia swobodnego przemieszczania się pobytu polegające na dążeniu do unikania nadmiernego obciążenia tego państwa i w związku z tym — na ograniczaniu kręgu beneficjentów stypendiów do osób wykazujących określony stopień zintegrowania ze społeczeństwem tego państwa. Powtórzył także ugruntowane stanowisko, że dowód wymagany przez państwo członkowskie w celu powołania się na istnienie takiej rzeczywistej więzi nie powinien mieć charakteru zbyt wykluczającego przez niesłuszne faworyzowanie jednej okoliczności, która niekoniecznie musi być reprezentatywna dla rzeczywistego i skutecznego stopnia powiązania wnioskodawcy z danym państwem członkowskim z wyłączeniem wszelkich innych reprezentatywnych okoliczności ${ }^{61}$. Trybunał ocenę tej kwestii pozostawił sądowi krajowemu, zwrócił przy tym uwagę, że warunek przebywania w państwie członkowskim może być dowodem na istnienie wystarczającej więzi studenta $z$ danym państwem, lecz jednocześnie pojedynczy warunek zamieszkania pociąga za sobą ryzyko wykluczenia możliwości korzystania ze stypendium przez tych studentów, którzy nie zamieszkują w Niemczech przez nieprzerwany okres trzech lat bezpośrednio poprzedzających rozpoczęcie studiów za granicą, jednocześnie są dostatecznie związani ze społeczeństwem niemieckim. Więź taką wykazywać będą osoby posiadające obywatelstwo tego państwa, które przyznaje stypendium, i pobierające w nim przez znaczący okres naukę, lub też z innych względów — więzi zawodowych, rodzinnych, umiejętności

59 Wyrok Morgan i Bucher, EU:C:2007:626, pkt 43-44.

60 Ibidem, pkt 46. Trybunał odnotował przy tym, iż sąd odsyłający sam wskazywał, że warunkiem stopień zintegrowania ze społeczeństwem, którego państwo członkowskie mogłoby słusznie wymagać, należy uznać za wystarczający z tego względu, że skarżące przed sądem krajowym zostały wychowane w Niemczech i tam uczęszczały do szkoły.

61 Wyrok Prinz i Seeberger, EU:C:2013:524, pkt 36-37. 
językowych, innych więzi społecznych lub gospodarczych ${ }^{62}$. Zbliżoną argumentację przyjął Trybunał Sprawiedliwości w wyroku Meneses ${ }^{63}$ oraz Martens ${ }^{64}$.

W wyroku Elrick rząd niemiecki podnosił argument, jakoby uregulowanie krajowe miało na celu przyznanie pomocy na kształcenie za granicą wyłącznie na rzecz kształcenia oferującego osobie uczącej się najlepsze szanse na rynku pracy. Kształcenie dające niskie kwalifikacje nie zasługuje zatem na przyznanie pomocy na kształcenie za granicą, ponieważ w niewielkiej mierze zwiększałoby szanse zainteresowanej osoby uczącej się na rynku pracy. Trybunał Sprawiedliwości nie dostrzegł takiej zależności, zważywszy na fakt, że wymóg dwuletniego czasu trwania edukacji był pozbawiony związku z poziomem wybranego kształcenia ${ }^{65}$.

Po drugie, z prawa Unii Europejskiej wynika uprawnienie do ochrony przed dyskryminacją pracowników migrujących. Przepisy krajowe ograniczające dostęp do stypendiów i pożyczek na odbywanie studiów w innych państwach członkowskich mogą bowiem wpływać nie tylko na sytuację obywateli tego państwa, które takie stypendia lub pożyczki oferuje, lecz także na sytuację obywateli innych państw członkowskich, w szczególności pracowników migrujących. Te same przepisy holenderskie, które były przedmiotem wątpliwości sądu krajowego i analizy Trybunału Sprawiedliwości w wyroku Martens, zostały także już wcześniej zakwestionowane przez Komisję Europejską. Komisja wskazała na niezgodność przepisów holenderskich, na podstawie których obywatel innego państwa członkowskiego mógł ubiegać się o stypendium na finansowanie studiów, jeżeli zamieszkiwał legalnie w Niderlandach przez co najmniej trzy lata w okresie sześciu lat poprzedzających przyjęcie go na studia, ze swobodą przepływu pracowników, tzn. art. 45 TFUE i art. 7 ust. 2 rozporządzenia 492/2011.

W wyroku Komisja p. Niderlandom (C-542/09) Trybunał wskazał, że zasada równego traktowania, wpisana zarówno do art. 45 TFUE, jak i do art. 7 rozporządzenia 492/2011, zakazuje nie tylko dyskryminacji jawnej opartej na przynależności państwowej, lecz również wszelkich ukrytych form dyskryminacji, które przez zastosowanie innych kryteriów rozróżnienia wywierają w rzeczywistości ten sam skutek. W szczególności do takiej dyskryminacji pośredniej dochodzi wtedy, gdy przepisy krajowe wymagają precyzyjnie określonego okresu zamieszkiwania, ponieważ działają one na niekorzyść pracowników migrujących i pracowników przygranicznych będących obywatelami innych państw członkowskich, gdyż to właśnie osoby nieposiadające miejsca zamieszkania w państwie przyjmującym są najczęściej cudzoziemcami ${ }^{66}$. Po tym jak Trybunał stwierdził, że przepisy niderlandzkie wprowadzają odmienne traktowanie stanowiące pośrednią dyskryminację, przypomniał, że takie odmienne traktowanie jest zakazane na mocy art. 7

\footnotetext{
62 Ibidem, pkt 38.

63 Wyrok Meneses, EU:C:2013:683, pkt 34-39.

64 Wyrok Martens, EU:C:2015:118, pkt 36-40.

65 Wyrok Elrick, EU:C:2013:684, pkt 32-33.

66 Wyrok Komisja p. Niderlandom, EU:C:2012:346, pkt 37-38.
} 
ust. 2 rozporządzenia 492/2011, chyba że zostanie ono obiektywnie uzasadnione. Rząd niderlandzki argumentował w pierwszej kolejności, że przepisy krajowe mają na celu unikanie nieracjonalnych obciążeń budżetowych, zatem pomoc finansowa jest oferowana jedynie takim osobom, które wykazują wystarczający stopień integracji ze społeczeństwem tego państwa. Trybunał Sprawiedliwości odrzucił ten argument, wskazując, że w przypadku pracowników migrujących i przygranicznych okoliczność uczestniczenia w rynku pracy państwa członkowskiego tworzy zasadniczo wystarczająco silny związek ze społecznością tego państwa członkowskiego, pozwalający tym pracownikom korzystać w nim z zasady równego traktowania z pracownikami krajowymi w odniesieniu do przywilejów socjalnych. Zasada niedyskryminacji ze względu na obywatelstwo znajduje zastosowanie nie tylko do wszystkich warunków pracy i zatrudnienia, lecz także do wszystkich przywilejów socjalnych związanych lub niezwiązanych z umową o pracę, z jakich korzystają zwykle pracownicy krajowi, w związku z ich statusem pracownika i z racji zamieszkiwania na terytorium krajowym. Zdaniem Trybunału zintegrowanie ze społeczeństwem danego państwa członkowskiego wynika w szczególności z tego, że pracownik migrujący przyczynia się również — w związku ze składkami, jakie opłaca on w przyjmującym państwie członkowskim z racji pracy najemnej, jaką tam wykonuje — do finansowania polityki społecznej tego państwa i powinien korzystać z niej na takich samych zasadach jak pracownicy krajowi ${ }^{67}$. Jednocześnie Trybunał Sprawiedliwości uznał, że powoływane przez rząd niderlandzki uzasadnienie opierające się na celu propagowania mobilności studentów stanowi nadrzędny wzgląd interesu ogólnego, mogący uzasadniać ograniczenie zasady niedyskryminacji ze względu na obywatelstwo. Trybunał uznał jednak, iż rząd niderlandzki nie wykazał, że przepisy niderlandzkie są proporcjonalne, tzn. nie wykraczają poza to, co jest niezbędne do realizacji zamierzonego celu, i ostatecznie stwierdził w wyroku naruszenie zobowiązań państwa członkowskiego ciążących na mocy art. 45 TFUE i art. 7 ust. 2 rozporządzenia 492/2011.

Podsumowując tę część rozważań, należy stwierdzić, że przepisy krajowe regulujące zasady przyznawania stypendiów i pożyczek studenckich na finansowanie studiów w innych państwach członkowskich niż państwo, które je oferuje, mogą wchodzić w zakres prawa UE w dwóch przypadkach. Po pierwsze, gdy stanowią one ograniczenie swobody przemieszczania się i pobytu obywateli tego państwa, które oferuje stypendia i pożyczki, jeżeli przepisy takie stawiają te osoby w gorszej sytuacji (np. skutkują odmową przyznania pomocy) tylko z tego powodu, że skorzystały one ze swobody przemieszczania się (orzecznictwo Morgan i Bucher, Prinz i Seeberg, Meneses, Elrick i Martens). Swoboda państw członkowskich w kształtowaniu przepisów regulujących zasady przyznawania takich stypendiów i pożyczek jest ograniczona z uwagi na to, że przepisy ograniczające swobodę przemieszczania się muszą być uzasadnione nadrzędnymi względami w intere-

67 Ibidem, pkt 65-66. 
sie publicznym oraz proporcjonalne do zamierzonego celu. Takimi względami mogą być: zamiar upewnienia się, że studenci ukończą naukę w krótkim terminie, przyczyniając się tym samym do równowagi finansowej systemu edukacyjnego zainteresowanego państwa członkowskiego ${ }^{68}$, zamiar unikania nadmiernego obciążenia budżetu krajowego i w związku z tym ograniczanie przyznawania pomocy do jedynie takich studentów, którzy wykażą określony stopień zintegrowania ze społeczeństwem tego państwa ${ }^{69}$, a także wspieranie mobilności studentów ${ }^{70}$. W dotychczasowym orzecznictwie Trybunału Sprawiedliwości próżno jednak szukać pozytywnych przykładów uznania przepisów krajowych za proporcjonalne, albowiem Trybunał albo samodzielnie stwierdza nieodpowiedniość warunków przyznawania stypendiów do realizacji wskazanych przez państwa celów, albo pozostawia tę kwestię sądowi krajowemu. Można jednak się spodziewać, że szczególnie wnikliwie Trybunał będzie analizował wymaganie, by obywatel państwa członkowskiego dodatkowo zamieszkiwał przez określony czas w tym państwie, ponieważ co do zasady więzią łączącą taką osobę z danym państwem jest po prostu obywatelstwo.

Po drugie, przepisy regulujące przyznawanie stypendiów i pożyczek na studia w innych państwach członkowskich mogą prowadzić do dyskryminacji ze względu na obywatelstwo pracowników migrujących, w tym pracowników przygranicznych, zakazanej na podstawie art. 45 oraz art. 7 ust. 2 rozporządzenia 492/2011. W tym przypadku oczywiście zakazana jest wszelka dyskryminacja ze względu na obywatelstwo, zarówno bezpośrednia jak i pośrednia, przy czym ta druga może być zgodna z prawem UE, jeżeli jest uzasadniona przyczynami obiektywnymi niezwiązanymi z obywatelstwem i proporcjonalna do celów zamierzonych przez dane państwo członkowskie (Komisja p. Niderlandom, C-542/09).

Brakującym ogniwem, które jak dotąd nie było przedmiotem analizy Trybunału Sprawiedliwości, jest kwestia, czy przepisy krajowe regulujące na studia za granicą mogłyby być uznane także za dyskryminację pośrednią zakazaną na podstawie art. 18 TFUE $\mathrm{w}$ związku z art. 21 TFUE, tzn. w tych przypadkach, gdy o stypendium lub pożyczkę ubiegałby się obywatel UE zamieszkujący w tym państwie oferującym taką pomoc, który jednocześnie nie jest pracownikiem migrującym (a zatem osobą nieaktywną zawodowo). Chodzi zatem o sytuację, gdy obywatel państwa członkowskiego A mieszka w państwie członkowskim B i ubiega się o stypendium na studia w państwie członkowskim C. Gdyby zastosować argumentację Trybunału Sprawiedliwości przyjętą w wyroku Grzelczyk i Bidar, należałoby odpowiedzieć, że takie przepisy krajowe stanowią także dyskryminację pośrednią zakazaną na podstawie art. 18 TFUE, z uwagi na to, że mamy do

68 Wyrok Morgan i Bucher, EU:C:2007:626, pkt 36.

69 Ibidem,pkt 43; wyrok Prinz i Seeberger, EU:C:2013:524, pkt36; wyrok Meneses, EU:C:2013:683, pkt 34; wyrok Martens, EU:C:2015:118, pkt 36.

70 Wyrok Meneses, EU:C:2013:683, pkt 49. 
czynienia z obywatelem UE, który skorzystał ze swobody przemieszczania się zagwarantowanej na podstawie art. 21 TFUE i z tego względu przysługuje mu ochrona - w szczególności przed dyskryminacją ze względu na obywatelstwo. Jednocześnie zastosowanie miałby wówczas art. 24 ust. 2 dyrektywy 2004/38/ WE, który pozwala państwom członkowskim na ograniczenie kręgu beneficjentów stypendiów i pożyczek do osób, które posiadają prawo stałego pobytu.

\subsection{ZAKRES PODMIOTOWY UPRAWNIEŃ WYNIKAJACYCH Z PRAWA UE} W ZAKRESIE DOSTĘPU DO STYPENDIÓW I POŻYCZEK NA STUDIA ZA GRANICĄ

Kwestia ta została pośrednio omówiona już wyżej przy okazji wskazywania zakresu przedmiotowego uprawnień związanych z dostępem do stypendiów i pożyczek na studia za granicą. Z tego względu w tym miejscu wystarczy jedynie wskazać, że, po pierwsze, na uprawnienia wynikające z prawa UE w kontekście dostępu do stypendiów i pożyczek na studia za granicą mogą powołać się obywatele tego państwa, które takie stypendia i pożyczki oferuje, w sytuacji gdy uznają, że warunki przyznawania takiej pomocy ograniczają ich swobodę przemieszczania się gwarantowaną na podstawie art. 21 TFUE. Oczywiście konieczne jest wówczas jeszcze wykazanie, że pogorszenie sytuacji obywatela tego państwa (pozbawienie go możliwości uzyskania stypendium lub pożyczki) jedynie z tego względu, że skorzystał ze swobody przemieszczania się i zamieszkał w innym państwie członkowskim, nie jest właściwie uzasadnione i nie jest proporcjonalne do zamierzonych przez to państwo celów.

Po drugie, na uprawnienia wynikające z prawa UE w kontekście dostępu do stypendiów i pożyczek na studia za granicą mogą powołać się także aktywni zawodowo obywatele UE, którzy zamieszkują w państwie oferującym takie stypendia i pożyczki. W odniesieniu do pracowników Trybunał Sprawiedliwości wyraźnie potwierdził taką możliwość w wyroku Komisja p. Niderlandom (C-542/09), lecz biorąc pod uwagę brzmienie art. 24 ust. 1 dyrektywy 2004/38/WE, wydaje się, że takie same uprawnienia miałyby inne osoby wymienione w tym przepisie, tzn. osoby wykonujące działalność na własny rachunek, osoby, które zachowują status pracownika lub osoby działającej na własny rachunek oraz członkowie ich rodzin.

Po trzecie wreszcie, jak dotąd nie została rozstrzygnięta kwestia, czy na uprawnienia wynikające z prawa UE mogliby powoływać się obywatele UE zamieszkujący w państwie członkowskim oferującym stypendia lub pożyczki, lecz nieposiadający obywatelstwa tego państwa, a przy tym osoby nieaktywne zawodowo (czyli niewymienione w art. 24 ust. 1 dyrektywy 2004/38/WE). Stosując przez analogię orzecznictwo Trybunału Sprawiedliwości w sprawach Bidar i Forster, należałoby stwierdzić, że, po pierwsze, takie osoby mogłyby powoływać się na zasadę niedyskryminacji ze względu na obywatelstwo. Jednocześnie jednak państwo członkowskie miałoby obowiązek zapewnić ochronę przed pośrednią dyskryminacją jedynie takim osobom, które wykazują wystarczającą więź ze spo- 
łeczeństwem tego państwa. Jak wynika z art. 24 ust. 2 dyrektyw 2004/38/WE taką więź wykazują osoby, które posiadają prawo stałego pobytu w rozumieniu tej dyrektywy (czyli zamieszkiwały co najmniej przez pięć lat w tym państwie).

\section{ZAKOŃCZENIE}

Na obecnym etapie rozwoju prawa Unii Europejskiej obywatele UE korzystają z pełnej ochrony przed dyskryminacją ze względu na obywatelstwo w zakresie warunków dostępu do kształcenia wyższego i uniwersyteckiego w państwie członkowskim przyjmującym. Na podstawie art. 18 TFUE w związku z art. 21 TFUE zakazana jest bowiem zarówno dyskryminacja bezpośrednia (wyrok Gravier), jak również pośrednia (wyrok Bressol). Ochrona ta przysługuje wszystkim obywatelom UE korzystającym ze swobody przemieszczania się i pobytu w państwie członkowskim innym niż jego państwo pochodzenia bez względu na stopień integracji ze społeczeństwem państwa przyjmującego.

Wynikające z prawa UE reguły dotyczące dostępu do stypendiów i pożyczek studenckich są bardziej skomplikowane, albowiem Trybunał Sprawiedliwości akceptuje swobodę państw członkowskich do ograniczenia kręgu beneficjentów do takiej formy pomocy studentom, do osób, które wykazują wystarczający stopień integracji ze społeczeństwem państwa oferującego pomoc. W tym zakresie stanowisko Trybunału Sprawiedliwości jest spójne w odniesieniu zarówno do stypendiów i pożyczek oferowanych przez państwo przyjmujące na studia w tym państwie, jak również do stypendiów i pożyczek oferowanych przez dane państwo na studia w innych państwach UE, a nawet poza granicami Unii.

W odniesieniu do obywateli UE podejmujących studia w państwie członkowskim innym niż ich państwo obywatelstwa, stanowisko Trybunału Sprawiedliwości ewoluowało w kierunku ograniczania uprawnień do stypendiów i pożyczek studenckich: od promowania solidarności między państwami członkowskimi w wyroku Grzelczyk do akceptacji przysługujących państwom członkowskim kompetencji ograniczania dostępności takich stypendiów lub pożyczek jedynie dla osób, które wykazują pewien stopień integracji ze społeczeństwem państwa oferującego taką pomoc w wyrokach Bidar i Forster. O ile zatem co do zasady prawo UE chroni takie osoby przed dyskryminacją bezpośrednią i pośrednią ze względu na obywatelstwo, krąg beneficjentów tej ochrony może zostać skutecznie (zgodnie z prawem UE) zawężony przez państwa wykazujące więź, np. w wyniku legalnego zamieszkiwania przez okres pięciu lat na terytorium państwa oferującego taką pomoc.

Z kolei w odniesieniu do stypendiów i pożyczek na pokrycie studiów poza granicami państwa, które je oferuje, prawo Unii Europejskiej uległo ewolucji w kierunku przyznania ochrony w pierwszej kolejności obywatelom tego właśnie 
państwa. Trybunał Sprawiedliwości przez uznanie, że warunki przyznawania takich stypendiów i pożyczek mogą niekiedy pogarszać sytuację obywateli danego państwa członkowskiego jedynie z tego względu, że skorzystali ze swobody przemieszczania się, sformułował zasadę, że takie przepisy mogą stanowić ograniczenie swobody przemieszczania się. W konsekwencji, dla uznania że są one zgodne z prawem UE, wymagają uzasadnienia celem obiektywnym (nieopartym na obywatelstwie) oraz przeprowadzenia analizy proporcjonalności. W ten sposób zakres ochrony wynikający z prawa UE uległ znacznemu rozszerzeniu, zaś swoboda państw członkowskich w tym względzie — znacznemu zawężeniu.

Dodatkowo, jeżeli już państwo członkowskie wprowadza system takich stypendiów lub pożyczek (chociaż nie jest do tego zobligowane na mocy prawa UE), wówczas jest związane także obowiązkiem poszanowania zasady niedyskryminacji ze względu na obywatelstwo. Jak dotychczas, Trybunał Sprawiedliwości potwierdził taką tezę w wyroku Komisja p. Niderlandom w odniesieniu do pracowników migrujących, w tym pracowników przygranicznych, i członków ich rodzin. Źródłem ochrony przed dyskryminacją pośrednią ze względu na obywatelstwo był w tym przypadku art. 45 TFUE i art. 7 ust. 2 rozporządzenia 492/2011. Swoboda państw członkowskich także w tym zakresie została ograniczona, dyskryminacja pośrednia może bowiem być uznana za dopuszczalną jedynie wówczas, gdy jest uzasadniona obiektywnymi względami niezwiązanymi z obywatelstwem i proporcjonalna do zamierzonego przez państwo celu. Pozostaje oczekiwać, czy Trybunał Sprawiedliwości będzie miał okazję sformułować podobne stanowisko na gruncie art. 18 TFUE w związku z art. 21 TFUE — w odniesieniu do studentów, obywateli UE nieaktywnych zawodowo oraz jaki będzie zakres ochrony przed dyskryminacją wynikający z prawa UE.

\title{
FREE MOVEMENT OF STUDENTS IN THE EUROPEAN UNION - RIGHT TO EDUCATION, ACCESS TO EDUCATION AND ACCESS TO GRANTS IN THE TRANSNATIONAL CONTEXT
}

\author{
Summary
}

The right to education, recognised by Article 14 of the Charter of Fundamental Rights of the European Union must be analysed and interpreted in the light of the previous evolution of EU law in this domain, as well as of the preceding jurisprudence of the Court of Justice. In the present state of EU law there is no doubt that access to higher education as well as access to student grants or loans falls within the scope of EU law. Therefore the article contains the overview of where EU law stands at present in the domain of mobility of students. The main two fields of interest are: access to education of migrant students, when they move from their home Member State to a host Member State in order to undertake studies, as well as access to social benefits, namely student grants or loans, which enable or make easier the mobility of students. The second field of interest concerning student grants or loans is divided into two parts: the first concerns access to grants or 
loans accorded by the host Member State to migrant student; the second concerns access to grants or loans accorded by the home Member State to its own citizens in order to encourage them to study abroad. The analysis, on the one hand, reveals that the scope of application of EU law to the situation of migrant students, due to the jurisprudence of the CJEU, is very wide, which means the wide scope of rights accorded to students and the narrow scope of freedom left to the Member States. On the other hand, the analysis leads to a conclusion that the case of migrant students is an exemplification of the challenges faced by the Union in the field of free movement, in particular the pressure to limit the social benefits for EU citizens exercising their right to free movement. 